Article

\title{
Exergy Analysis of a Pilot Parabolic Solar Dish-Stirling System
}

\author{
Ehsan Gholamalizadeh (D) and Jae Dong Chung * \\ Department of Mechanical Engineering, Sejong University, Seoul 05006, Korea; ehsan@sejong.ac.kr \\ * Correspondence: jdchung@sejong.ac.kr; Tel.: +82-2-3408-3776
}

Received: 26 July 2017; Accepted: 19 September 2017; Published: 21 September 2017

\begin{abstract}
Energy and exergy analyses were carried out for a pilot parabolic solar dish-Stirling System. The system was set up at a site at Kerman City, located in a sunny desert area of Iran. Variations in energy and exergy efficiency were considered during the daytime hours of the average day of each month in a year. A maximum collector energy efficiency and total energy efficiency of $54 \%$ and $12.2 \%$, respectively, were predicted in July, while during the period between November and February the efficiency values were extremely low. The maximum collector exergy efficiency was $41.5 \%$ in July, while the maximum total exergy efficiency reached $13.2 \%$. The values of energy losses as a percentage of the total losses of the main parts of the system were also reported. Results showed that the major energy and exergy losses occurred in the receiver. The second biggest portion of energy losses occurred in the Stirling engine, while the portion of exergy loss in the concentrator was higher compared to the Stirling engine. Finally, the performance of the Kerman pilot was compared to that of the EuroDish project.
\end{abstract}

Keywords: solar energy; solar-thermal technology; solar parabolic dish-Stirling; exergy analysis; efficiency

\section{Introduction}

A number of energy sources can be used as preferred alternatives to fossil fuels, based on economic, environmental, and safety considerations. Among these, solar energy is widely believed to be superior to other alternative energy forms, because it can be provided sustainably without harming the environment [1].

One of the most promising solar systems is the parabolic solar dish-Stirling system. This system is a type of concentrating solar-thermal technology which converts solar energy into electrical power. The system consists of a solar collector and a Stirling engine. The collector has two main parts: a solar concentrator and a thermal receiver. The main role of the collector is to provide thermal energy, which drives the Stirling engine. The concentrator is a parabolic dish which concentrates solar radiation onto the aperture of the receiver. The receiver consists of an aperture located at the focal point of the parabolic dish, and an absorber. The aperture accommodates the solar radiation provided by the concentrator, and then, the absorber transfers the thermal energy to the working fluid of the Stirling engine. Then, the Stirling engine converts the input thermal energy into mechanical energy, and finally, electricity is produced by using a generator.

A pilot dish-Stirling system was set up under specified meteorological conditions in Kerman City, Iran (latitude $30^{\circ} 17^{\prime}$ North and longitude $57^{\circ} 5^{\prime}$ East). The average solar irradiation of this area is more than $2000 \mathrm{kWh} / \mathrm{m}^{2}$ year, with about 2800 solar hours in a year [2]. The Kerman pilot system is shown in Figure 1. 


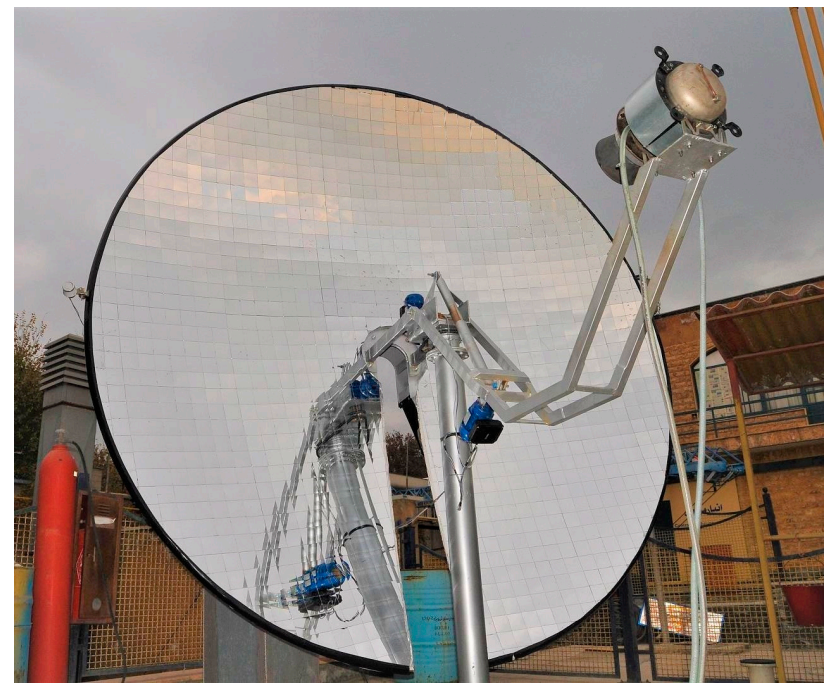

Figure 1. Kerman pilot parabolic dish-Stirling system.

The parabolic dish consisted of identical square $0.08 \mathrm{~m} \times 0.08 \mathrm{~m}$ glass/silver mirror panels with a thickness of $2 \mathrm{~mm}$. The dish diameter and the receiver aperture diameter of the collector of the Kerman pilot were $3 \mathrm{~m}$, and $0.12 \mathrm{~m}$, respectively, so that the concentration ratio was 625 . The collector rim angle was $45^{\circ}$. The receiver of the system was a directly illuminated tube, which can be operated only during the daytime (solar-only type). A 1-kW free-piston Stirling engine was installed in the Kerman pilot, using helium as the engine working fluid with maximum operating conditions of $800 \mathrm{~K}$ and 10 bars.

Generally, a parabolic solar dish-Stirling system is able to produce electricity at low, medium, and high temperature ranges [3,4]. Two parabolic dishes with a diameter of $1.6 \mathrm{~m}$ (stainless steel) and $2 \mathrm{~m}$ (aluminum) were examined by Nuwayhid et al. [5]. Wu et al. [6] evaluated the performance of a parabolic dish-Stirling module with the efficiency and power output of $20.6 \%$ and $18.54 \mathrm{~kW}$, respectively. Nepveu et al. [7] presented a thermal model 10-kW dish-Stirling system called a EuroDish unit. Li et al. [8] presented an approach to design large parabolic mirrors with highly reflective flat metal petals. Lovegrove et al. [9] also designed a solar parabolic dish with a $500 \mathrm{~m}^{2}$ concentrator area. A new solar dish configuration was developed by Ahmed [10], in which, compared to a usual dish, the focal point was located much closer to the dish, which enabled the rim angle value to reach up to $90^{\circ}$. A mathematical model was presented to assess the thermal efficiency of the solar dish-Stirling engine [11].

Sripakagorn et al. [12] developed a prototype Stirling engine working at moderate temperatures. A techno-economic assessment of the $100 \mathrm{MW}$ solar thermal dish-Stirling technology was performed to estimate the thermal energy and the levelized energy cost [13]. A rim angle of $45^{\circ}$ was suggested for the design of the system solar collector by investigators [9,14-16], taking into consideration the highest concentration ratio and thermal performance. The effect of the distribution of the solar receiver radiation flux was examined by Mao et al. [17]. Ruelas et al. [18] developed a mathematical model and conducted numerical investigations to simulate a thermal model for a $3 \mathrm{~kW}$ Stirling engine. Based on a literature review, the energy and exergy performances were predicted by developing a numerical model for the Stirling engine coupled to the solar collector, implemented in the programing software Matlab R2016a.

In many rural regions of the desert areas of Iran, grid-connected electricity supplied by renewable energy is rarely available. The main goal of this study was to examine and report the performance and feasibility of a pilot solar dish-Stirling system in the Kerman province of Iran. Doing so under the available climatic conditions allows the development of a solar electricity generation program in the rural area. To accomplish this, the energy efficiency and the exergy efficiency of the system were 
examined. The simulations were carried out during daytime hours on the average day of each month of a year, as recommended in Reference [1].

\section{Methodology}

\subsection{Solar Radiation Calculation}

To simulate the annual energy efficiency and exergy efficiency of the Kerman pilot solar dish-Stirling system, the amount of solar irradiance reaching the dish on the site during a year was calculated. Since the area of the receiver aperture is much smaller than the area of the dish, only beam radiation is effective [19], hence, only beam radiation will be directed onto the absorbing surface. The beam solar irradiance was calculated using the following equations:

The extraterrestrial radiation flux is calculated by an accurate equation, as given below [19]:

$$
G_{o n}=G_{s c}(1.000110+0.034221 \cos B+0.001280 \sin B+0.000719 \cos 2 B+0.000077 \sin 2 B)
$$

with $B=(n-1) \times 360 / 365$.

The declination can be calculated as follows [19]:

$\delta=(180 / \pi)(0.006918-0.399912 \cos B+0.070257 \sin B-0.006758 \cos 2 B+0.000907 \sin 2 B-0.002697 \cos 3 B+0.00148 \sin 3 B)$

The zenith angle of the sun is calculated using the following equation [19]:

$$
\cos \theta_{z}=\cos \varphi \cos \delta \cos \omega+\sin \varphi \sin \delta
$$

The atmospheric transmittance for beam radiation is calculated as below [19]:

$$
\tau_{b}=a_{0}+a_{1} \exp \left(-k / \cos \theta_{z}\right)
$$

The beam solar irradiance on a tilted surface is calculated as [19]:

$$
G=G_{o n} \tau_{b} \cos \theta
$$

Since the solar dish concentrator is continuously tracking the sun using a two-axis tracking mechanism, the incident angle is always equal to zero $(\cos \theta=1)$. The full tracking configuration collects the maximum possible sunshine [19].

\subsection{The Collector Model}

The focal distance and the concentration ratio of the collector are calculated as below, respectively [20]:

$$
\begin{gathered}
f=\frac{d_{d}}{4 \tan \left(\psi_{\text {rim }} / 2\right)} \\
C=\left(\frac{d_{d}}{d_{a p}}\right)^{2}
\end{gathered}
$$

To estimate the convective heat transfer coefficient through the receiver cavity, the Nusselt number of the natural convection, forced convective heat transfer coefficient and total convective heat transfer coefficient can be calculated as given in Equations (8)-(10), respectively [21,22]:

$$
\begin{gathered}
N u_{\text {natural }}=0.088 \cdot G r^{1 / 3} \cdot\left(T_{\text {cav }} / T_{\text {amb }}\right)^{0.18} \cdot(\cos \theta)^{2.47} \cdot\left(d_{\text {ap }} / d_{\text {cav }}\right)^{-0.982 \cdot\left(d_{\text {ap }} / d_{\text {cav }}\right)+1.12} \\
h_{\text {forced }}=0.1967 \cdot v^{1.849} \\
h_{\text {total }}=h_{\text {natural }}+h_{\text {forced }}
\end{gathered}
$$


The reflected and emitted radiation heat transfers from the receiver cavity can also be calculated with the Equations (11) and (12), respectively:

$$
\begin{aligned}
& \dot{Q}_{\text {reflected }}=\left(1-\alpha_{e f f}\right) \cdot \eta_{c o n c} \cdot G \cdot A_{d} \\
& \dot{Q}_{\text {emitted }}=\varepsilon \cdot A_{a p} \cdot \sigma \cdot\left(T_{c a v}^{4}-T_{a m b}^{4}\right)
\end{aligned}
$$

where $\alpha_{e f f}=\alpha_{c a v} /\left[\alpha_{c a v}+\left(1-\alpha_{c a v}\right)\left(A_{a p} / A_{c a v}\right)\right]$.

The conduction, convection, radiation and total losses from the receiver are calculated by Equations (13)-(16), respectively:

$$
\begin{gathered}
\dot{Q}_{\text {conduction }}=\frac{T_{\text {cav }}-T_{\text {amb }}}{\ln \left[\left(\frac{d_{\text {cav }}}{2}+\delta_{\text {insul }}\right) / \frac{d_{\text {cav }}}{2}\right] /\left(2 \pi k_{\text {insul }} L_{c a v}\right)} \\
\dot{Q}_{\text {convection }}=h_{\text {total }} \cdot A_{\text {cav }} \cdot\left(T_{\text {cav }}-T_{\text {amb }}\right) \\
\dot{Q}_{\text {radiation }}=\dot{Q}_{\text {emitted }}+\dot{Q}_{\text {reflected }} \\
\dot{Q}_{\text {total loss }}=\dot{Q}_{\text {convection }}+\dot{Q}_{\text {conduction }}+\dot{Q}_{\text {radiation }}
\end{gathered}
$$

The efficiency of the receiver is calculated as:

$$
\eta_{\text {rec }}=1-\frac{\dot{Q}_{\text {total }, \text { loss }}}{\eta_{\text {conc }} \cdot G \cdot A_{d}}
$$

The thermal input energy to the Stirling engine is calculated as follows:

$$
\dot{Q}_{S E}=\eta_{r e c} \cdot \eta_{c o n c} \cdot G \cdot A_{d}
$$

\subsection{The Stirling Engine Model}

The thermal efficiency of the Stirling engine is calculated as given below [23]:

$$
\eta_{S E}=\left(1-\frac{T_{L}}{T_{H}}\right) \cdot \eta_{X} \cdot \eta_{\Delta p}
$$

where the incomplete regeneration $\left(\eta_{X}\right)$ and pressure losses $\left(\eta_{\Delta p}\right)$ can be calculated by Equations (20) and (21), respectively [24]:

$$
\begin{gathered}
\eta_{X}=\frac{1}{1+\frac{\left(X_{1} y+X_{2}(1-y)\right) \cdot c_{v}}{R \cdot \ln \varepsilon_{v}} \sqrt{\left(1-\frac{T_{L}}{T_{H}}\right)}} \\
\eta_{\Delta p}=1-\frac{\frac{w}{w_{S}} \gamma\left(1+\tau^{1 / 2}\right) \ln \varepsilon_{v}+5\left(\frac{w}{w_{s}}\right)^{2} N_{S}}{\tau \cdot \eta_{C C} \cdot \eta_{X} \ln \varepsilon_{v}}-\frac{3(0.94+0.045 w) 10^{5}}{16 p_{m}\left(\tau \cdot \eta_{C C} \cdot \eta_{X} \ln \varepsilon_{v}\right) /\left(\varepsilon_{v}+1\right)(\tau+1)}
\end{gathered}
$$

\subsection{The Energy and Exergy Efficiency and Performance}

The total exergy input of the solar power to the parabolic dish can be calculated as follows [25]:

$$
E x_{i n}=G A_{d}\left(1-\frac{4}{3} \frac{T_{a m b}}{T_{S}}+\frac{1}{3}\left(\frac{T_{a m b}}{T_{S}}\right)^{4}\right)
$$


The energy efficiency of the collector is determined by the ratio of the thermal energy transferred to the Stirling engine to the solar energy reaching the concentrator as below:

$$
\eta_{, \text {coll }}=\frac{\dot{Q}_{S E}}{G A_{d}}
$$

The useful exergy gain and exergy efficiency of the collector can be calculated by Equations (24) and (25), respectively:

$$
\begin{gathered}
E x_{u}=\dot{Q}_{S E}\left(1-\frac{T_{a m b}}{T_{r e c}}\right) \\
\eta_{\text {, coll }}=\frac{E x_{u}}{E x_{i n}}
\end{gathered}
$$

The total energy efficiency can be calculated as the product of the efficiencies of all the components of the system as follows:

$$
\eta_{\text {,total }}=\eta_{\text {coll }} \eta_{S E} \eta_{g e n}
$$

The total power output of the system can then be estimated as follows:

$$
P_{S E}=G A_{d} \eta_{, \text {total }}
$$

The total exergy efficiency of the system is calculated as below:

$$
\eta_{, \text {total }}=\frac{P_{S E}}{E x_{i n}}
$$

\section{Results and Discussion}

According to the weather parameters recorded by the weather bureau of Kerman City, the performances of the system throughout the year were simulated. Table 1 shows the ambient temperature and wind speed of the site during the working hours on 15 June. The corresponding beam solar irradiances on horizontal ground, as calculated by the model, are also shown in Table 1.

Table 1. Wind speed $(\mathrm{m} / \mathrm{s})$, ambient temperature $\left({ }^{\circ} \mathrm{C}\right)$, and horizontal beam solar irradiance $\left(\mathrm{W} / \mathrm{m}^{2}\right)$ at the Kerman site recorded on 15 June.

\begin{tabular}{cccccccccccc}
\hline & \multicolumn{10}{c}{ Time (h) } \\
\cline { 2 - 12 } & $\mathbf{8}$ & $\mathbf{9}$ & $\mathbf{1 0}$ & $\mathbf{1 1}$ & $\mathbf{1 2}$ & $\mathbf{1 3}$ & $\mathbf{1 4}$ & $\mathbf{1 5}$ & $\mathbf{1 6}$ & $\mathbf{1 7}$ & $\mathbf{1 8}$ \\
\hline Wind Speed & 6.4 & 4.4 & 4.1 & 6.1 & 6.4 & 8 & 9.5 & 7.8 & 7.6 & 6.3 & 6.9 \\
Ambient Temperature & 31 & 31.8 & 33.1 & 34.2 & 35.1 & 36 & 35.5 & 35.7 & 35.8 & 35.7 & 34.5 \\
Beam Solar Irradiance & 374.9 & 579.8 & 755.2 & 885.1 & 959.1 & 971.3 & 921 & 811.9 & 652.7 & 456.9 & 245.7 \\
\hline
\end{tabular}

The Kerman pilot was able to produce about 600 Watts electrical power at midday in the middle of June. The measurement was recorded when the system acquired a steady state condition, considering the power output did not change appreciably at intervals of $10 \mathrm{~min}$ around midday. The EuroDish system also produced $7.55 \mathrm{~kW}$ power output at the direct normal irradiance of $773 \mathrm{~W} / \mathrm{m}^{2}$ in the middle of May [26]. The analytical model was validated by comparing the predicted power output with the experimental data of the two projects, and the relative errors between measured data and results obtained from the model were calculated (Table 2). Results revealed that the predicted power outputs were in close agreement with the measured data.

Based on the model, analyses of the energy efficiency and exergy efficiency of the collector and the entire system during daytime hours of the average day of all months in a year were carried out. 
Table 2. Comparison between numerical results and measured power output of the Kerman project and EuroDish project.

\begin{tabular}{cccc}
\hline \multirow{2}{*}{ Project } & \multicolumn{2}{c}{ Power Output (kW) } & \multirow{2}{*}{ Relative Error (\%) } \\
\cline { 2 - 3 } & Measured & Analytic & \\
\hline EuroDish & 7.55 & 7.66 & $1.44 \%$ \\
Kerman Pilot & 0.60 & 0.629 & $4.61 \%$ \\
\hline
\end{tabular}

\subsection{Energy Efficiency and Exergy Efficiency of the Collector}

The values of the energy efficiency of the collector during the daytime hours on the average day of each month of the year are shown in Figure 2. The energy efficiency of the collector was very low in the early morning and later evening, and it reached its maximum value at about midday. A maximum energy efficiency of about $54 \%$ was estimated for a midday in July. It can also be seen that during the period between November and February, the collector efficiency was extremely low.

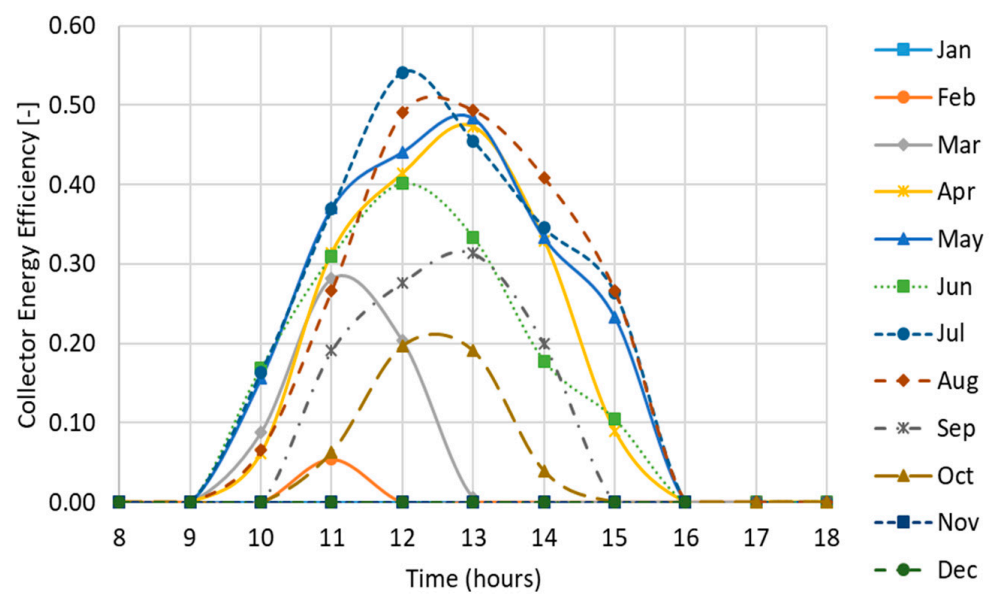

Figure 2. Collector energy efficiency during the daytime hours on the average day of each month.

Figure 3 shows the exergy efficiency of the collector for all daytime hours on the average day of each month of the year. The collector exergy efficiency had the same trend as the collector energy efficiency. A maximum value of $41.5 \%$ is predicted for the collector exergy efficiency in July.

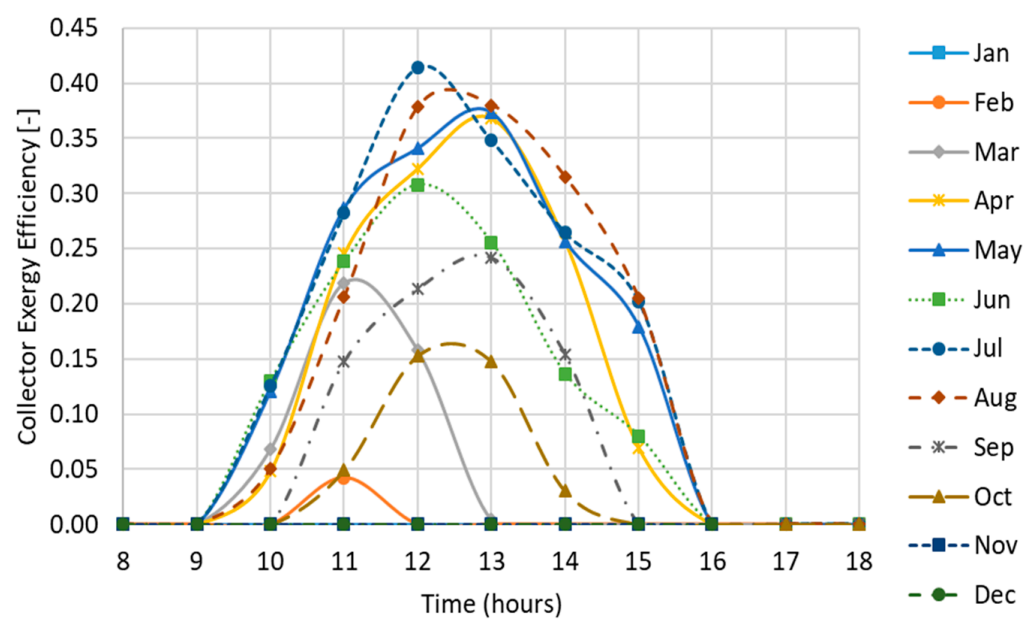

Figure 3. Collector exergy efficiency during the daytime hours on the average day of each month. 


\subsection{Total Energy Efficiency and Exergy Efficiency of the System}

The total energy efficiency values of the system during daytime hours on the average day of each month of the year are shown in Figure 4. Like the collector energy efficiency, the total energy efficiency was very low in the early morning and later evening while it reached its maximum value of about $12.2 \%$ at midday in July. During the period between November and February, the total energy efficiency was also extremely low.

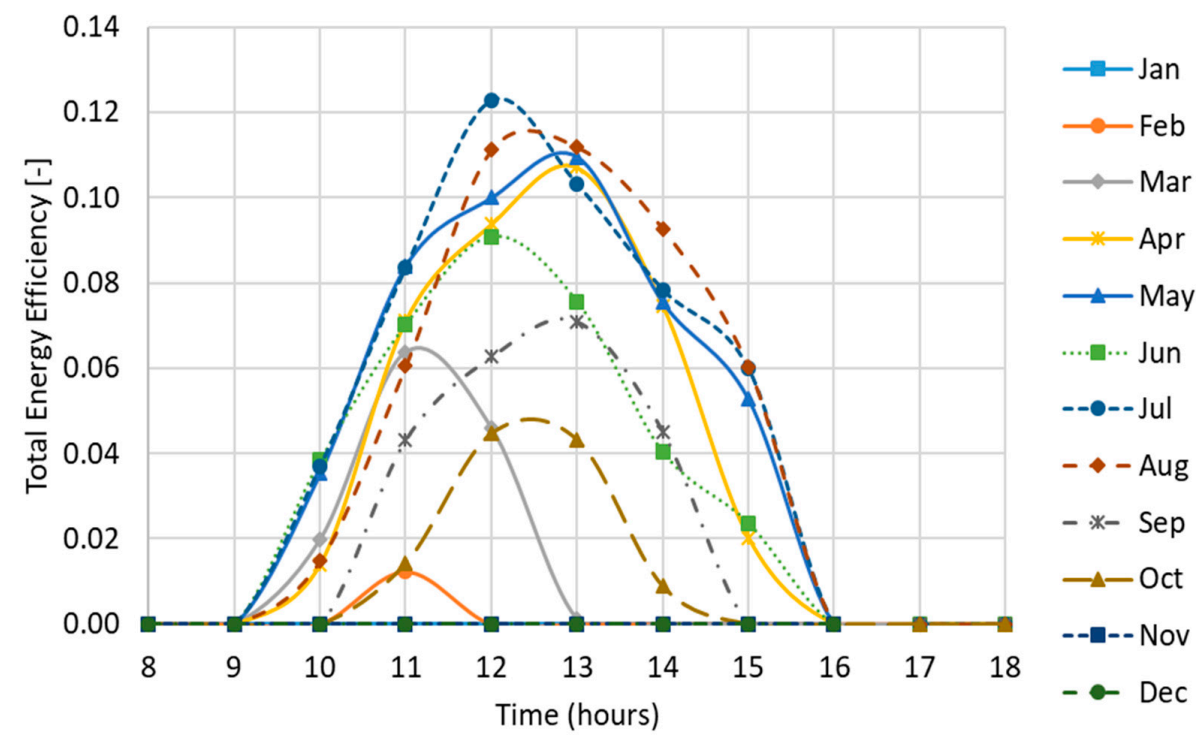

Figure 4. Total energy efficiency during the daytime hours on the average day of each month.

Figure 5 shows that the total exergy efficiency of the system followed the same trend as the total energy efficiency. It can be seen that the values of the exergy efficiency were slightly higher compared to the total energy efficiency at the corresponding time. A maximum value of about $13.2 \%$ is estimated in July.

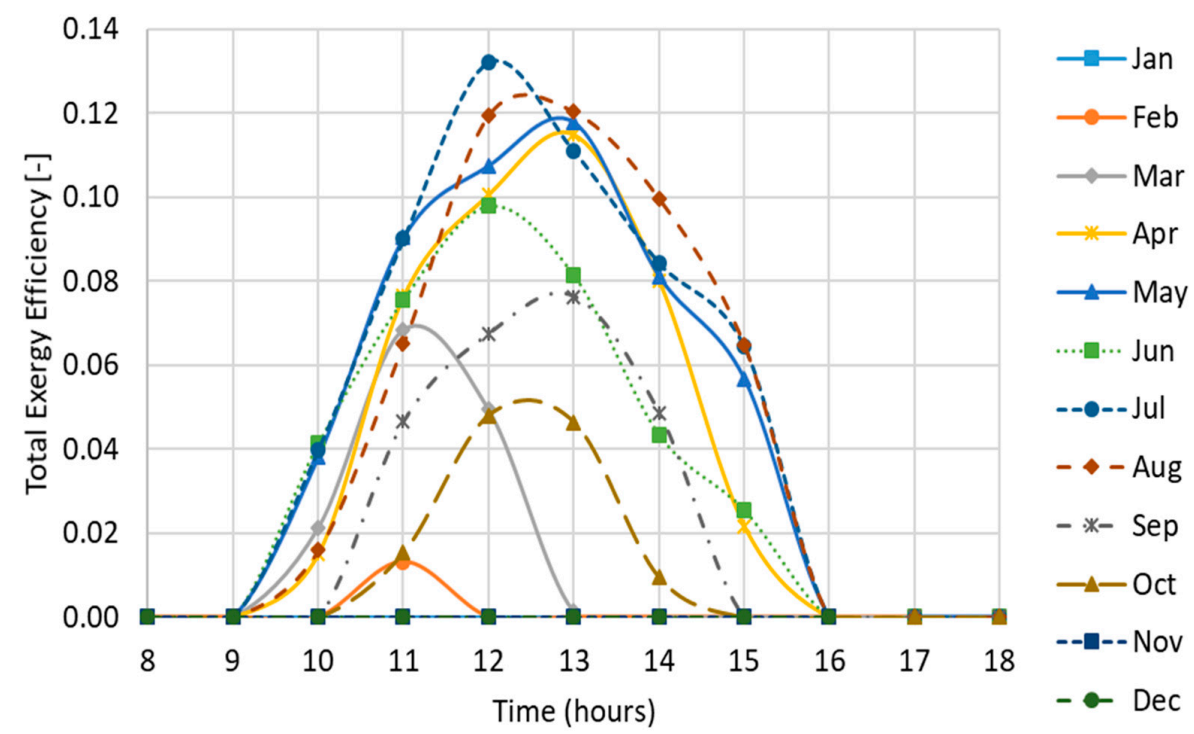

Figure 5. Total exergy efficiency during the daytime hours on the average day of each month.

The results of the energy and exergy analyses of the Kerman pilot system and EuroDish project at midday in the middle of June are shown in Tables 3 and 4, respectively. Table 3 shows that, in the 
Kerman pilot, the major energy and exergy losses occurred in the receiver, with values of $3.53 \mathrm{~kW}$ and $2.52 \mathrm{~kW}$, respectively. The energy efficiency values of the collector and system in the Kerman pilot were $40 \%$ and $9.1 \%$, respectively, while those for the exergy efficiency were $31 \%$ and $9.8 \%$, respectively.

Table 3. Results of the Kerman pilot solar dish-Stirling system at midday in the middle of June.

\begin{tabular}{ccccccccc}
\hline & $\begin{array}{c}\text { Energy } \\
\text { Input (kW) }\end{array}$ & $\begin{array}{c}\text { Energy } \\
\text { Output (kW) }\end{array}$ & $\begin{array}{c}\text { Energy } \\
\text { Loss (kW) }\end{array}$ & $\begin{array}{c}\text { Exergy } \\
\text { Input (kW) }\end{array}$ & $\begin{array}{c}\text { Exergy } \\
\text { Output (kW) }\end{array}$ & $\begin{array}{c}\text { Exergy } \\
\text { Loss (kW) }\end{array}$ & $\begin{array}{c}\text { Energy } \\
\text { Efficiency }\end{array}$ & $\begin{array}{c}\text { Exergy } \\
\text { Efficiency }\end{array}$ \\
\hline Concentrator & 6.92 & 6.31 & 0.61 & 6.43 & 4.50 & 1.93 & 0.91 & 0.70 \\
Receiver & 6.31 & 2.78 & 3.53 & 4.50 & 1.98 & 2.52 & 0.44 & 0.44 \\
Stirling Engine & 2.78 & 0.63 & 2.15 & 1.98 & 0.63 & 1.35 & 0.23 & 0.32 \\
Collector & 6.92 & 2.78 & 4.14 & 6.43 & 1.98 & 4.45 & 0.40 & 0.31 \\
Overall & 6.92 & 0.63 & 6.29 & 6.43 & 0.63 & 5.80 & 0.091 & 0.098 \\
\hline
\end{tabular}

Table 4 reveals that the major energy loss of the EuroDish project occurred in the engine, with a value of $17.05 \mathrm{~kW}$, while the major exergy loss occurred in the receiver, with a value of $13.57 \mathrm{~kW}$. In addition, the energy efficiency values of the collector and the system were $54 \%$ and $17 \%$, respectively, while those for the exergy efficiency were $43 \%$ and $19 \%$, respectively.

Table 4. Results of the EuroDish project at midday in the middle of June.

\begin{tabular}{ccccccccc}
\hline & $\begin{array}{c}\text { Energy } \\
\text { Input (kW) }\end{array}$ & $\begin{array}{c}\text { Energy } \\
\text { Output (kW) }\end{array}$ & $\begin{array}{c}\text { Energy } \\
\text { Loss (kW) }\end{array}$ & $\begin{array}{c}\text { Exergy } \\
\text { Input (kW) }\end{array}$ & $\begin{array}{c}\text { Exergy } \\
\text { Output (kW) }\end{array}$ & $\begin{array}{c}\text { Exergy } \\
\text { Loss (kW) }\end{array}$ & $\begin{array}{c}\text { Energy } \\
\text { Efficiency }\end{array}$ & $\begin{array}{c}\text { Exergy } \\
\text { Efficiency }\end{array}$ \\
\hline Concentrator & 46.39 & 40.50 & 5.89 & 43.14 & 29.57 & 13.57 & 0.87 & 0.69 \\
Receiver & 40.50 & 25.16 & 15.34 & 29.57 & 18.37 & 11.20 & 0.62 & 0.62 \\
Stirling Engine & 25.16 & 8.11 & 17.05 & 18.37 & 8.11 & 10.26 & 0.32 & 0.44 \\
Collector & 46.39 & 25.16 & 21.23 & 43.14 & 18.37 & 24.77 & 0.54 & 0.43 \\
Overall & 46.39 & 8.11 & 38.28 & 43.14 & 8.11 & 35.03 & 0.17 & 0.19 \\
\hline
\end{tabular}

The energy losses of the main parts of the system, as a percentage of the total system losses, for the Kerman pilot and EuroDish project are illustrated in Figure 6a,b, respectively. Figure 6a shows that, in the Kerman pilot, $56.1 \%$ of the total energy loss occurred in the receiver, while $34.2 \%$ occurred in the Stirling engine. In the EuroDish project, the total energy loss of the receiver and the Stirling engine were $40 \%$ and $44.6 \%$, respectively (Figure $6 \mathrm{~b}$ ). In both systems, the smallest percentage of energy loss occurred in the concentrator.

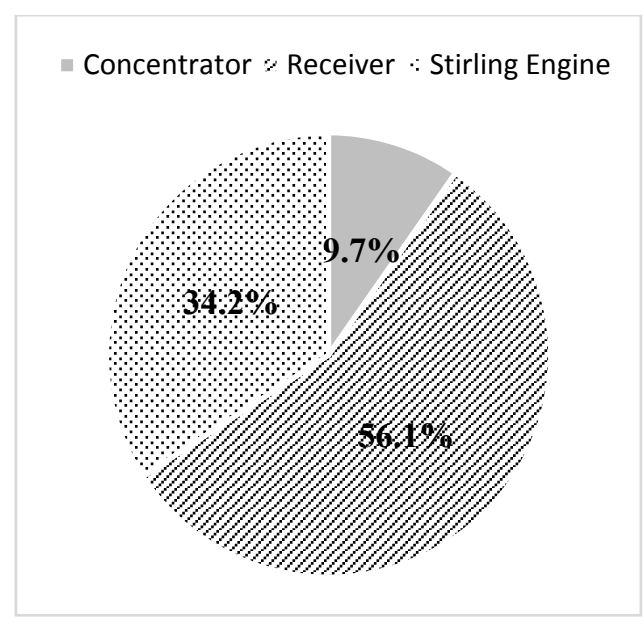

(a)

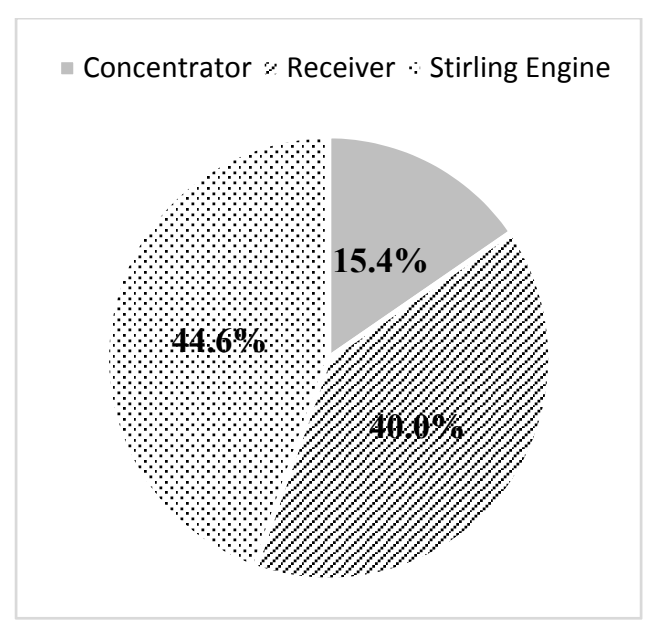

(b)

Figure 6. Energy losses of main parts of (a) the Kerman pilot; (b) EuroDish project as a percentage of total energy losses.

Figure 7 shows the corresponding exergy losses as a percentage of the total losses of the main parts of the Kerman system and the EuroDish project. In the Kerman pilot, the major portion of exergy 
loss occurred in the receiver, with $43.4 \%$ of the total exergy loss, while in the EuroDish project it occurred in the concentrator, with $38.7 \%$ of the total exergy loss. In addition, Figure 7 a shows that in the Kerman pilot, the second biggest portion of exergy loss occurred in the concentrator, with a value of $33.3 \%$, while the Stirling engine had the least portion of exergy loss, with a value of $23.3 \%$. Figure $7 \mathrm{~b}$ illustrates that in the EuroDish project, the portion of exergy loss in the receiver and the engine were almost the same. It can also be seen that in both systems the portion of exergy loss in the concentrator was significantly higher than that for the energy loss. It was found that, in the Kerman pilot, the largest energy and exergy losses occurred in the receiver, while in the EuroDish project the largest energy and exergy losses occurred in the engine and concentrator.

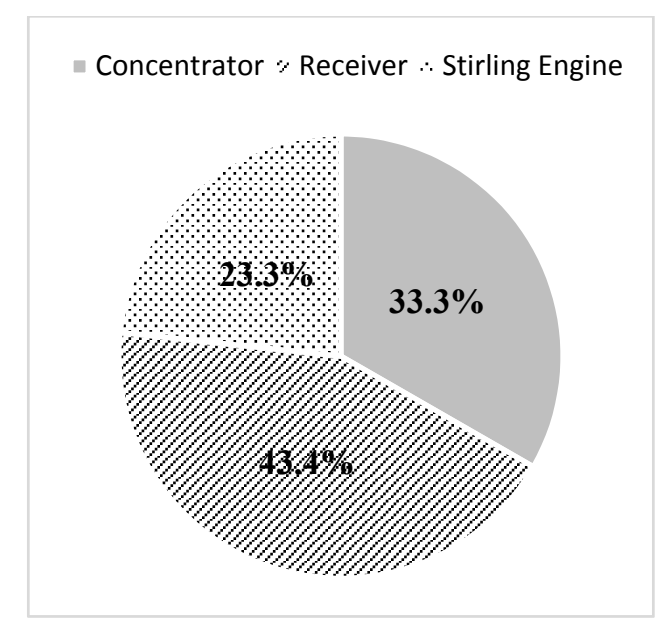

(a)

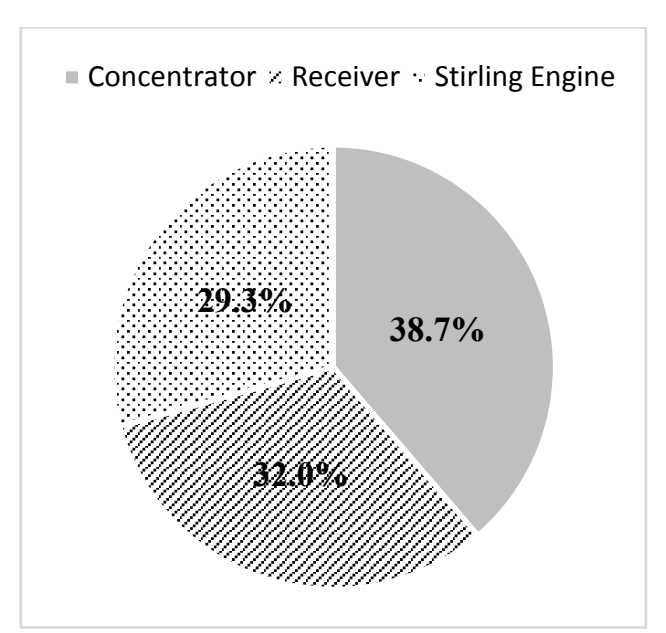

(b)

Figure 7. Exergy loss of the main parts of (a) the Kerman pilot; (b) EuroDish project as a percentage of total energy loss.

\section{Conclusions}

This study analyzed the energy efficiency and exergy efficiency of a pilot parabolic solar dish-Stirling System. This pilot, called the Kerman pilot, was set up under specified meteorological conditions in Kerman City, Iran (latitude $30^{\circ} 17^{\prime}$ North and longitude $57^{\circ} 5^{\prime}$ East). It had a collector with a dish diameter of $3 \mathrm{~m}$, and a concentration ratio of 625 , connected to a 1-kW Stirling engine. The calculations were performed during daytime hours on the average day of all months in a year. The results revealed that the variations in the energy efficiency and exergy efficiency trends were the same throughout the year. The energy and exergy efficiency values were very low in early morning and later evening and reached their maximum values at about midday.

The maximum collector energy and exergy efficiency values at midday in July were $54 \%$ and $41.5 \%$, respectively. The maximum total energy and exergy efficiency values of the system were $12.2 \%$ and $13.2 \%$, respectively. In addition, during the period between November and February, the efficiency values of the system were extremely low.

Moreover, when the energy and exergy losses of the main parts of the system in the middle of June were compared, it was found that the main losses occurred in the receiver.

Finally, the energy and exergy losses as a percentage of the total losses for the main parts of the system were reported. The portion of total energy losses in the receiver, the Stirling engine and the concentrator were $56.1 \%, 34.2 \%$ and $9.7 \%$, respectively, while the total exergy losses for those parts were $43.4 \%, 23.3 \%$ and $33.3 \%$, respectively. Therefore, the second biggest portion of exergy loss occurred in the concentrator, while the energy loss was comparatively low in the concentrator, and the Stirling engine had the lowest portion of the exergy loss. 
The results of the Kerman pilot were also compared to those of the EuroDish project. Comparing the results of the Kerman pilot and the EuroDish project revealed that the portion of energy and exergy losses in the receiver of the Kerman pilot was comparatively high. Hence, a more appropriate receiver must be designed and installed for the Kerman pilot.

It can be concluded that considering both the energy efficiency and exergy efficiency of the main components of the solar parabolic dish-Stirling system is a useful approach to analyze the performance of the system.

Acknowledgments: This research was supported by Basic Science Research Program through the National Research Foundation of Korea (NRF) funded by the Ministry of Education (No. 2017R1D1A1B05030422).

Author Contributions: Ehsan Gholamalizadeh and Jae Dong Chung conceptualized the analysis; Ehsan Gholamalizadeh performed the analysis; Jae Dong Chung is in charge of project; Ehsan Gholamalizadeh wrote original draft; Jae Dong Chung wrote and reviewed.

Conflicts of Interest: The authors declare no conflict of interest.

\section{Nomenclature}

A

area $\left(\mathrm{m}^{2}\right)$

$a_{0}, a_{1} \quad$ constants of atmospheric transmittance equation for beam radiation

C concentration ratio

$c_{p} \quad$ specific heat at constant pressure $(\mathrm{J} /(\mathrm{kg} \cdot \mathrm{K}))$

$c_{v} \quad$ specific heat at constant volume $(\mathrm{J} /(\mathrm{kg} \cdot \mathrm{K}))$

d diameter $(\mathrm{m})$

Ex Exergy

$f \quad$ focal distance $(\mathrm{m})$

G beam solar irradiance $\left(\mathrm{W} / \mathrm{m}^{2}\right)$

$G_{o n} \quad$ extraterrestrial radiation incident on the plane normal to the radiation on the nth day of the year $\left(\mathrm{W} / \mathrm{m}^{2}\right)$

$G_{s c} \quad$ solar constant; $=1367\left(\mathrm{~W} / \mathrm{m}^{2}\right)$

Gr Grashof number

$h \quad$ convective heat transfer coefficient $\left(\mathrm{W} /\left(\mathrm{m}^{2} \cdot \mathrm{K}\right)\right)$

$k \quad$ thermal conductivity $(\mathrm{W} /(\mathrm{m} \cdot \mathrm{K}))$; constant of atmospheric transmittance equation for beam radiation

L $\quad$ Length (m)

$N_{s} \quad$ number of screens in regenerator

$\mathrm{Nu} \quad$ Nusselt number

$n \quad$ day number of the year

$P \quad$ power output (W)

$p \quad$ pressure $(\mathrm{Pa})$

Pr Prandtl number

$\dot{\mathrm{Q}} \quad$ heat transfer rate $(\mathrm{W})$

$R \quad$ gas constant $(\mathrm{J} /(\mathrm{kg} \cdot \mathrm{K}))$

$\Delta r \quad$ beam spread (m)

$v \quad$ wind speed $(\mathrm{m} / \mathrm{s})$

$w \quad$ piston speed $(\mathrm{m} / \mathrm{s})$

$w_{s} \quad$ sound speed $(\mathrm{m} / \mathrm{s})$

$X \quad$ regenerative losses coefficient

$x \quad$ direction

y adjusting coefficient

Greek symbols

$\alpha \quad$ absorptivity

$\gamma \quad$ specific heat ratio

$\delta \quad$ declination, thickness (m)

$\varepsilon \quad$ emissivity

$\varepsilon_{v} \quad$ engine volume ratio 


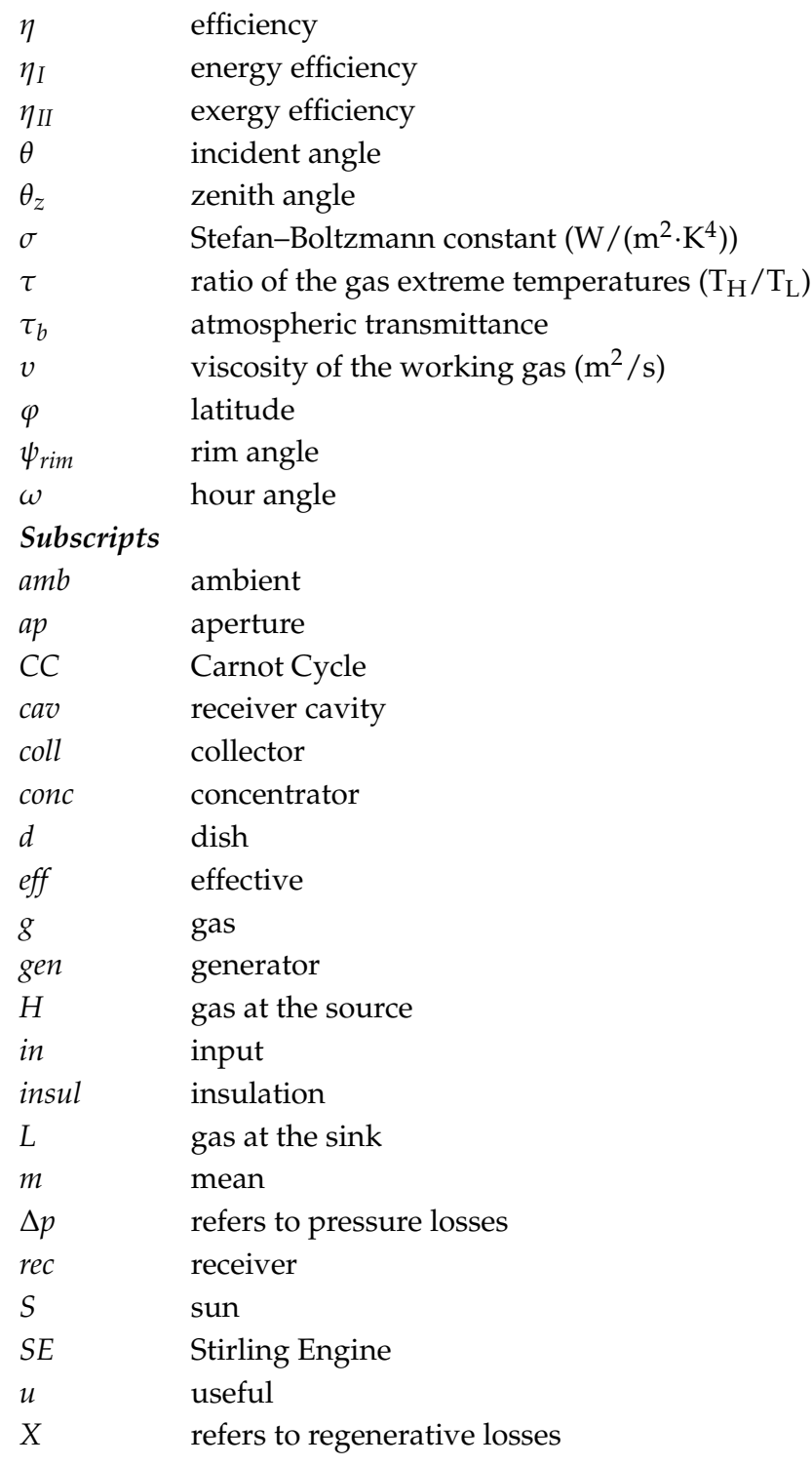

\section{References}

1. Kalogirou, S.A. Chapter 2: Environmental Characteristics. In Solar Energy Engineering, 2nd ed.; Academic Press: Boston, MA, USA, 2014.

2. Gholamalizadeh, E.; Mansouri, S.H. A comprehensive approach to design and improve a solar chimney power plant: A special case-Kerman project. Appl. Energy 2013, 102, 975-982. [CrossRef]

3. Mancini, T.; Heller, P.; Butler, B.; Osborn, B.; Schiel, W.; Goldberg, V.; Buck, R.; Diver, R.; Andraka, C.; Moreno, J. Dish-Stirling Systems: An Overview of Development and Status. J. Sol. Energy Eng. 2003, 125, 135-151. [CrossRef]

4. Kongtragool, B.; Wongwises, S. A review of solar-powered Stirling engines and low temperature differential Stirling engines. Renew. Sustain. Energy Rev. 2003, 7, 131-154. [CrossRef]

5. Nuwayhid, R.Y.; Mrad, F.; Abu-Said, R. The realization of a simple solar tracking concentrator for university research applications. Renew. Energy 2001, 24, 207-222. [CrossRef]

6. Wu, S.Y.; Xiao, L.; Cao, Y.; Li, Y.R. A parabolic dish/AMTEC solar thermal power system and its performance evaluation. Appl. Energy 2010, 87, 452-462. [CrossRef]

7. Nepveu, F.; Ferriere, A.; Bataille, F. Thermal model of a dish/Stirling systems. Sol. Energy 2009, 83, 81-89. [CrossRef]

8. Li, L.; Dubowsky, S. A new design approach for solar concentrating parabolic dish based on optimized flexible petals. Mech. Mach. Theory 2011, 46, 1536-1548. [CrossRef] 
9. Lovegrove, K.; Burgess, G.; Pye, J. A new $500 \mathrm{~m}^{2}$ paraboloidal dish solar concentrator. Sol. Energy 2011, 85, 620-626. [CrossRef]

10. Cameron, M.; Ahmed, N.A. A novel solar concentrating dish for reduced manufacturing cost. Appl. Mech. Mater. 2014, 607, 368-375. [CrossRef]

11. Yaqi, L.; Yaling, H.; Weiwei, W. Optimization of solar-powered Stirling heat engine with finite-time thermodynamics. Renew. Energy 2011, 36, 421-427. [CrossRef]

12. Sripakagorn, A.; Srikam, C. Design and performance of a moderate temperature difference Stirling engine. Renew. Energy 2011, 36, 1728-1733. [CrossRef]

13. Abbas, M.; Boumeddane, B.; Said, N.; Chikouche, A. Dish Stirling technology: A 100 MW solar power plant using hydrogen for Algeria. Int. J. Hydrog. Energy 2011, 36, 4305-4314. [CrossRef]

14. Ahmadi, M.H.; Ahmadi, M.A.; Mellit, A.; Pourfayaz, F.; Feidt, M. Thermodynamic analysis and multi objective optimization of performance of solar dish Stirling engine by the centrality of entransy and entropy generation. Int. J. Electr. Power Energy Syst. 2016, 78, 88-95. [CrossRef]

15. Sup, B.A.; Zainudin, M.F.; Zanariah ShamsirAli, T.; Bakar, R.A.; Ming, G.L. Effect of rim angle to the flux distribution diameter in solar parabolic dish collector. Energy Procedia 2015, 68, 45-52. [CrossRef]

16. Reinalter, W.; Ulmer, S.; Heller, P.; Rauch, T.; Gineste, J.M.; Fernere, A.; Nepveu, F. Detailed performance analysis of a $10 \mathrm{~kW}$ dish/stirling system. J. Sol. Energy Eng. Trans. ASME 2008, 130, 11013. [CrossRef]

17. Mao, Q.; Shuai, Y.; Yuan, Y. Study on radiation flux of the receiver with a parabolic solar concentrator system. Energy Convers. Manag. 2014, 84. [CrossRef]

18. Ruelas, J.; Velázquez, N.; Cerezo, J. A mathematical model to develop a Scheffler-type solar concentrator coupled with a Stirling engine. Appl. Energy 2013, 101, 253-260. [CrossRef]

19. Duffie, J.A.; Beckman, W.A. Solar Engineering of Thermal Processes; Wiley: Hoboken, NJ, USA, 2013.

20. Stine, W.; Diver, R. A Compendium of Solar Dish/Stirling Technology; Report No. SAND93-7026; Sandia National Labs: Albuquerque, NM, USA, 1994.

21. Stine, W.B.; McDonald, C. Cavity Receiver Convective Heat Loss. In Proceedings of the International Solar Energy Society, Solar World Congress, Kobe, Japan, 4-8 September 1989.

22. Ma, R.Y. Wind Effects on Convective Heat Loss from a Cavity Receiver for a Parabolic Concentrating Solar Collector; Sandia National Laboratories: Albuquerque, NM, USA, 1993.

23. Bejan, A. Advanced Engineering Thermodynamics, 3rd ed.; Wiley: Hoboken, NJ, USA, 2006.

24. Petrescu, S.; Costea, M.; Harman, C.; Florea, T. Application of the Direct Method to irreversible Stirling cycles with finite speed. Int. J. Energy Res. 2002, 26, 589-609. [CrossRef]

25. Petela, R. Exergy of Heat Radiation. J. Heat Transf. 1964, 86, 187-192. [CrossRef]

26. García Granados, F.J.; Silva Pérez, M.A.; Ruiz-Hernández, V. Thermal Model of the EuroDish Solar Stirling Engine. J. Sol. Energy Eng. 2007, 130, 11014. [CrossRef] 